\title{
The Ancient Chinese Stone Bridge Reinforcement Repair Method and Quality Control
}

\author{
Ye Liang Agu Ransford Tetteh \\ School of Civil Engineering and Architecture, Zhejiang University of Science and Technology, Hangzhou \\ 310023, China.
}

\begin{abstract}
China is known as the "land of bridge", it architecture of bridge construction technology has a long history. A lot of this bridges, ancient stone bridge architecture has the creations in the history of world bridges that shows the wisdom of hard working craftsmen in ancient China. This research is to find out how damage ancient stone bridge are repair and quality control during the construction period. What's more the author is ensuring the related repairing and stability measures according to the above situations the measures of reinforcing old bridges. In the actual repair method of the bridge, analyzing the actual damages and provide suitable design, reasonable reinforcement repair method to achieve the best in the aspects of proper control and reinforcement construction of the stone bridge so that we can achieve the quality service.
\end{abstract}

Keywords: Key Stone Bridge, Reinforcement Repair Method, Quality Control.

DOI: $10.7176 / \mathrm{CER} / 12-4-03$

Publication date: April $30^{\text {th }} 2020$

\section{Introduction}

Guifang stone bridge is located in the East Street of Donghu street, Linping, Yuhang District, Hangzhou city. It is built on shangtanghe River from north to south. The climate is subtropical monsoon humid climate, with abundant rainfall, warm and humid. The annual average temperature is $16^{\circ} \mathrm{C}$, the annual extreme minimum temperature is $-14{ }^{\circ} \mathrm{C}$, the annual extreme maximum temperature is $42.1{ }^{\circ} \mathrm{C}$, the annual temperature is $37 \sim$ $38{ }^{\circ} \mathrm{C}$. The bridge is situated in the downtown area of Linping City, surrounded by numerous buildings and as a passage connecting the block used by residents. It reached the Beijing Hangzhou Grand Canal in the East and the main urban area of Hangzhou in the West and used to be one of the main waterways for the prosperity of local economy and commodity trade. According to the records of Renhe county published by Jiajing of Ming Dynasty, "the old name of Mao bridge is Xu Xuan, who was born in the Song Dynasty, Diyin and Cuan, and dozens of people from Taixue, Fu que, wrote to attack Jia Sidao. Later, he was also a Jinshi, ranking first in the list. The name of the villager is one gate, three shows, and the bridge name is "Guifang". The bridge was faced with some diseases that called for urgent repair work in order to sustain it for normal operational use.

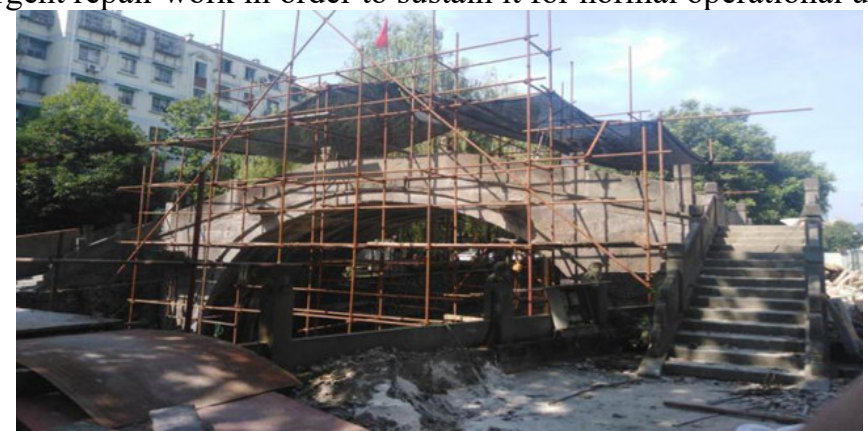

Figure 1: Site Construction Drawing of Guifang Stone Bridge

\section{Damages Caused on the Bridge}

\section{1 damage and disease of Guifang bridge stone}

According to the field survey, the overall status of Guifang bridge is as follows: 1) there is a large gap in the bottom slab of the bridge; 2) there is a pull-out crack between the corundum and the eyebrow stone; 3) the corundum is damaged and missing. 
Table1: damage and disease of Guifang bridge stone

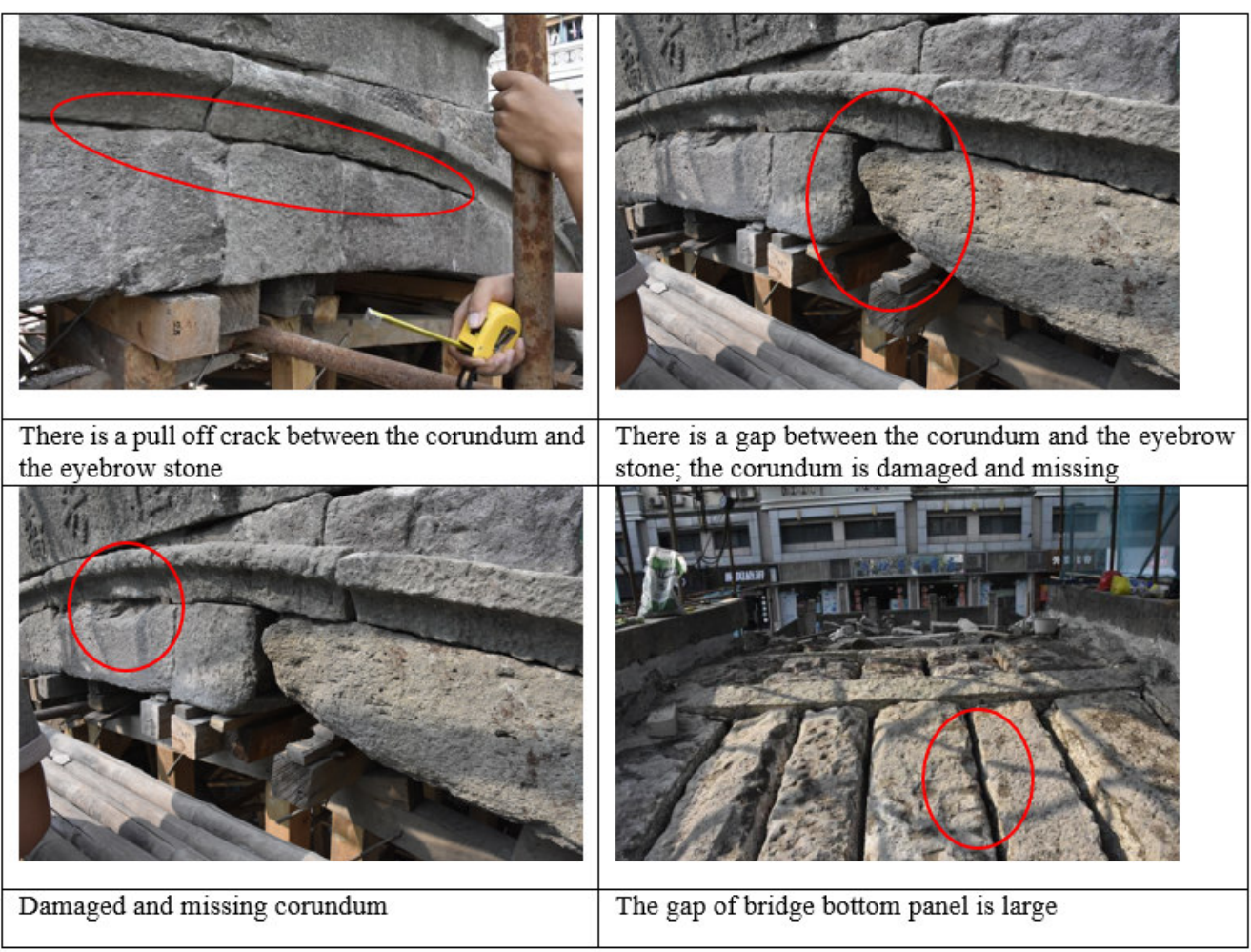

\subsection{Surface Strength Test}

Table 2 : Correction table of rebound meter reading

\begin{tabular}{|l|l|l|l|l|}
\hline \multirow{2}{*}{$\begin{array}{l}\text { Resilience } \\
\text { Value }\end{array}$} & \multicolumn{4}{|l|}{ Tilt Angle Correction (The Angle is Positive Upward and Negative Downward) } \\
\cline { 2 - 5 } & $+90^{\circ}$ & $+45^{\circ}$ & $-45^{\circ}$ & $-90^{\circ}$ \\
\hline 10 & & & 2.4 & 3.2 \\
\hline 20 & -5.4 & -3.5 & 2.5 & 3.4 \\
\hline 30 & -4.7 & -3.1 & 2.3 & 3.1 \\
\hline 40 & -3.9 & -2.6 & 2 & 2.7 \\
\hline 50 & -3.1 & -2.1 & 1.6 & 2.2 \\
\hline 60 & -2.3 & -1.6 & 1.3 & 1.7 \\
\hline
\end{tabular}


Table 3: Rebound Data

\begin{tabular}{|l|l|l|l|l|l|l|}
\hline Location Number & Direction & $\begin{array}{c}\text { Rebound } \\
\text { Maximum }\end{array}$ & $\begin{array}{c}\text { Rebound } \\
\text { Minimum }\end{array}$ & $\begin{array}{c}\text { Rebound } \\
\text { Average }\end{array}$ & $\begin{array}{c}\text { Correction } \\
\text { of Rebound } \\
\text { Value }\end{array}$ & $\begin{array}{c}\text { Converted } \\
\text { Compressive } \\
\text { Strength Value }\end{array}$ \\
\hline $\begin{array}{l}\text { Western side arch } \\
\text { ring }\end{array}$ & 48 & 16 & 35.2 & 35.2 & 53 \\
\hline Northwest side wall level & 51 & 26 & 44.7 & 44.7 & 85 \\
\hline Southwest side wall level & 52 & 19 & 35.4 & 35.4 & 53 \\
\hline Southeast side wall & level & 39 & 26 & 32.4 & 32.4 & 47 \\
\hline Northeast side wall & level & 54 & 20 & 37.8 & 37.8 & 61 \\
\hline East side arch ring & level & 50 & 24 & 37.8 & 37.8 & 61 \\
\hline $\begin{array}{l}\text { South side bridge } \\
\text { floor vertical }\end{array}$ & 45 & 22 & 33.8 & 36.7 & 58 \\
\hline $\begin{array}{l}\text { Middle bridge } \\
\text { bottom plate }\end{array}$ & vertical & 51 & 26 & 39.3 & 42.0 & 73 \\
\hline $\begin{array}{l}\text { North side bridge } \\
\text { floor }\end{array}$ & vertical & 61 & 34 & 48.4 & 50.2 & 110 \\
\hline $\begin{array}{l}\text { Transverse lock } \\
\text { stone at bridge } \\
\text { bottom }\end{array}$ & vertical & 54 & 28 & 43.7 & 45.7 & 90 \\
\hline
\end{tabular}

The surface strength of Guifang bridge stone is high, there is slight weathering phenomenon, and local weathering is serious. The surface strength of bridge floor is high, and the surface strength of arch ring and side wall on both sides is relatively low.

\section{Repair material}

\subsection{Optimization of Field Material Ratio}

\subsection{Optimization and Debugging of Site Proportion}

Table 4: Chemical Composition of Hydraulic Lime (wt\%)

\begin{tabular}{|l|l|l|l|l|l|l|l|l|}
\hline Component & $\mathrm{CaO}$ & $\mathrm{SiO}_{2}$ & $\mathrm{Al}_{2} \mathrm{O}_{3}$ & $\mathrm{MgO}$ & $\mathrm{Fe}_{2} \mathrm{O}_{3}$ & $\mathrm{~K}_{2} \mathrm{O}$ & $\mathrm{SO}_{3}$ & $\mathrm{TiO}_{2}$ \\
\hline Hydraulic Lime & 70.7 & 15.2 & 5.32 & 2.64 & 2.33 & 1.84 & 1.00 & 0.36 \\
\hline
\end{tabular}

(1) Weigh on site according to the material foundation ratio;

(2) After weighing, manual mixing shall be carried out, consistency test shall be carried out on site, and mix proportion shall be optimized according to consistency;

(3) Mix again according to the optimized proportion, repeat the above steps, and finally carry out mold making, sample retention and on-site maintenance.

After the curing period is completed, test the bond strength, bending resistance and compression resistance of the sample test block on site

Table 5: basic material ratio

\begin{tabular}{|l|l|l|l|l|l|l|l|l|}
\hline Number & $\begin{array}{l}\text { Lime } \\
\%\end{array}$ & $\begin{array}{l}\text { Mineral } \\
\text { Powder } \\
\%\end{array}$ & $\begin{array}{l}\text { Adhesive } \\
\text { Additives \% }\end{array}$ & $\begin{array}{l}\text { Anti-Crack } \\
\text { Inhibitor\% }\end{array}$ & $\begin{array}{l}\text { Thixotropic } \\
\text { Inhibitor\% }\end{array}$ & $\begin{array}{l}\text { Binder } \\
\%\end{array}$ & Fiber\% & $\begin{array}{l}\text { Water Binder } \\
\text { Ratio (add } \begin{array}{l}\text { (\% } \\
\text { Water Reducer) }\end{array}\end{array}$ \\
\hline A & 40 & 60 & 0.8 (Repair) & 0.8 & 0.8 & 0.8 & 0.5 & 0.5 \\
\hline B & 40 & 60 & 0.8 (grouting) & 0.8 & 0.8 & 0.8 & 0.5 & 0.7 \\
\hline
\end{tabular}




\subsection{Field Consistency Test}
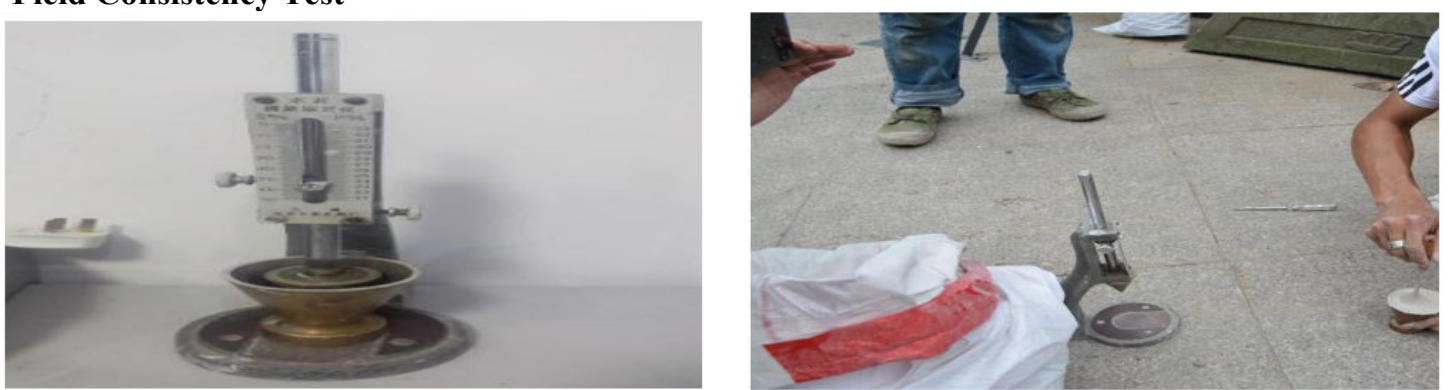

Figure 2 Field Consistency Test

(1) Wipe the sliding rod lightly with small lubricating oil so that the sliding rod can slide freely.

(2) Wipe the container and cone surface with a wet cloth, and put the mortar mixture into the container once, make the mortar surface is about $10 \mathrm{~mm}$ lower than the container mouth. Vibrate the container evenly for 25 times, shake container for 5-6 times to make the mortar surface flat, and then place the container on the base of the consistency tester.

(3) Loosen the brake screw, move the sliding rod downward, when the tip of the cone just contacts the mortar surface, tighten the brake screw, loosen the pointer screw, adjust the position of the pointer to the zero scale line, and tighten the pointer screw.

(4) Loosen the brake screw and count the time. When it 10 s, immediately tighten the screw and read the sinking depth (accuracy to $1 \mathrm{~mm}$ ) from the scale.

(5) The mortar in the slurry container is allowed to measure the consistency only once. When the measurement is repeated, the sample shall be taken again for measurement.

Finally, through the consistency test, the field test repair material from the original water to glue ratio of 0.5 consistency 66 to water to glue ratio of 0.45 consistency 45 .

\subsection{Optimization Results of Field Proportioning}

Through the actual construction process on site, confirm the results of material proportion after optimization on site.

Table 6: Material Ratio after Site Optimization

\begin{tabular}{|c|c|c|c|c|c|c|c|c|}
\hline Number & $\begin{array}{c}\text { Lime } \\
\%\end{array}$ & $\begin{array}{c}\text { Mineral } \\
\text { Powder \% }\end{array}$ & $\begin{array}{l}\text { Adhesive } \\
\text { Additives } \\
\%\end{array}$ & $\begin{array}{c}\text { Anti-crack } \\
\text { inhibitor\% }\end{array}$ & $\begin{array}{c}\text { Thixotropic } \\
\text { inhibitor\% }\end{array}$ & Binder\% & Fiber\% & $\begin{array}{c}\text { Water binder } \\
\text { ratio (add } 1 \% \\
\text { water reducer) }\end{array}$ \\
\hline A & 40 & 60 & $\begin{array}{c}0.8 \\
\text { (Repair) }\end{array}$ & 0.8 & 0.8 & 0.8 & 0.5 & 0.45 \\
\hline B & 40 & 60 & $\begin{array}{c}0.8 \\
\text { (grouting) }\end{array}$ & 0.8 & 0.8 & 0.8 & 0.5 & 0.6 \\
\hline
\end{tabular}

\section{Material Protection Technology Construction Site Guidance \\ 4.1 Site Material Preparation}

On site, according to the optimized material ratio, the construction guidance of material preparation is carried out, and the construction is reminded to pay attention to the difference between grouting and repair material ratio.

Table 7: Proportion of Grouting and Repair Grouting Materials

\begin{tabular}{|l|l|l|l|l|l|l|l|l|}
\hline Number & $\begin{array}{l}\text { Lime } \\
\%\end{array}$ & $\begin{array}{l}\text { Mineral } \\
\text { Powder } \\
\%\end{array}$ & $\begin{array}{l}\text { Adhesive } \\
\text { addition } \%\end{array}$ & $\begin{array}{l}\text { Anti-crack } \\
\text { inhibiter } \\
\%\end{array}$ & $\begin{array}{l}\text { Thixotropic } \\
\text { inhibitor \% }\end{array}$ & $\begin{array}{l}\text { Binder } \\
\%\end{array}$ & $\begin{array}{l}\text { Fiber } \\
\%\end{array}$ & $\begin{array}{l}\text { Water binder ratio } \\
\text { (add 1\% water } \\
\text { reducer })\end{array}$ \\
\hline A & 40 & 60 & $\begin{array}{l}0.8 \\
\text { (Repair) }\end{array}$ & 0.8 & 0.8 & 0.8 & 0.5 & 0.45 \\
\hline B & 40 & 60 & $\begin{array}{l}0.8 \\
\text { (grouting) }\end{array}$ & 0.8 & 0.8 & 0.8 & 0.5 & 0.6 \\
\hline
\end{tabular}



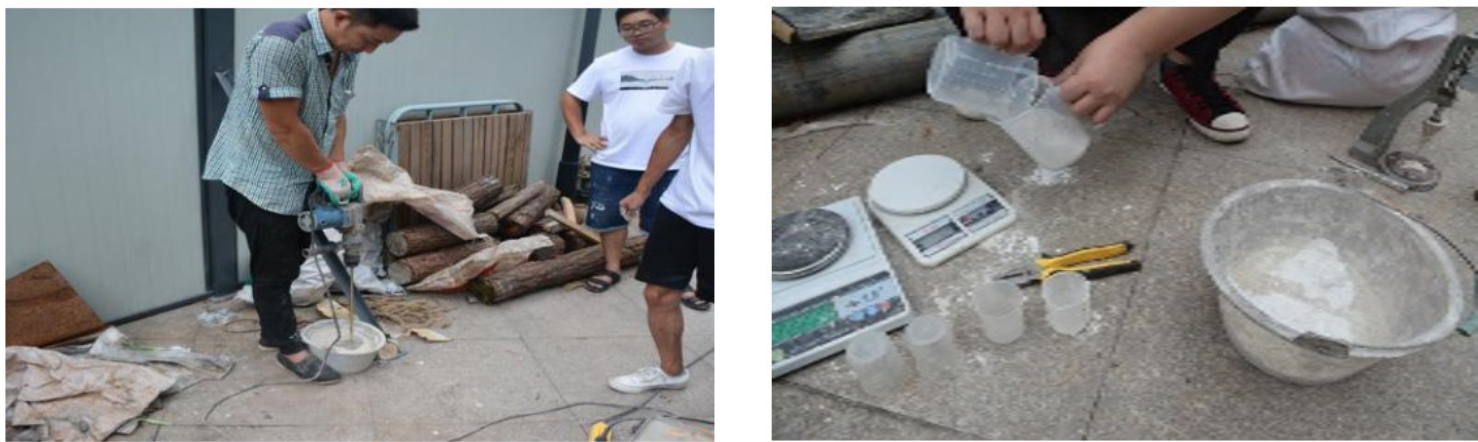

Figure 3 Site Material Preparation

\subsection{Arch Missing Repair Construction}

\subsubsection{Construction Process}

First, clean the pollutants inside the crack with brush, high-pressure air and vacuum cleaner, then seal the crack with repair materials, and finally fill the repair materials; pay attention to observation while filling the repair materials to prevent leakage of slurry in other places. If leakage occurs, plug it in time and clean it with ethanol. After grouting, the outer surface shall be treated as old. If the bonding part is large, wooden board and other tools shall be used for fixing.
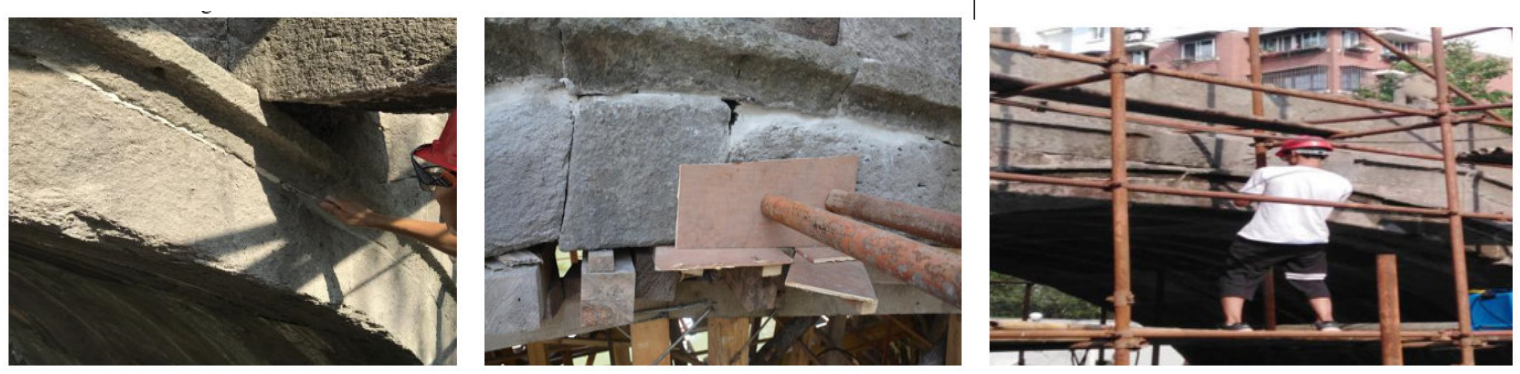

Figure 4 Construction Process

\subsubsection{Production of Sample Test Block on Site}

\section{A. Fabrication of Bond Test Block}

Put water, lime, mineral powder and various additives into corresponding containers according to the repair ratio after material optimization

(1).Mix manually and then mix evenly with mixer.

(2) Then make the drawing test block on the stone.

(3) Finally, the pull-out test block shall be cured for three days.

(4) After forming, the formwork shall be removed and placed near or under the bridge for maintenance.
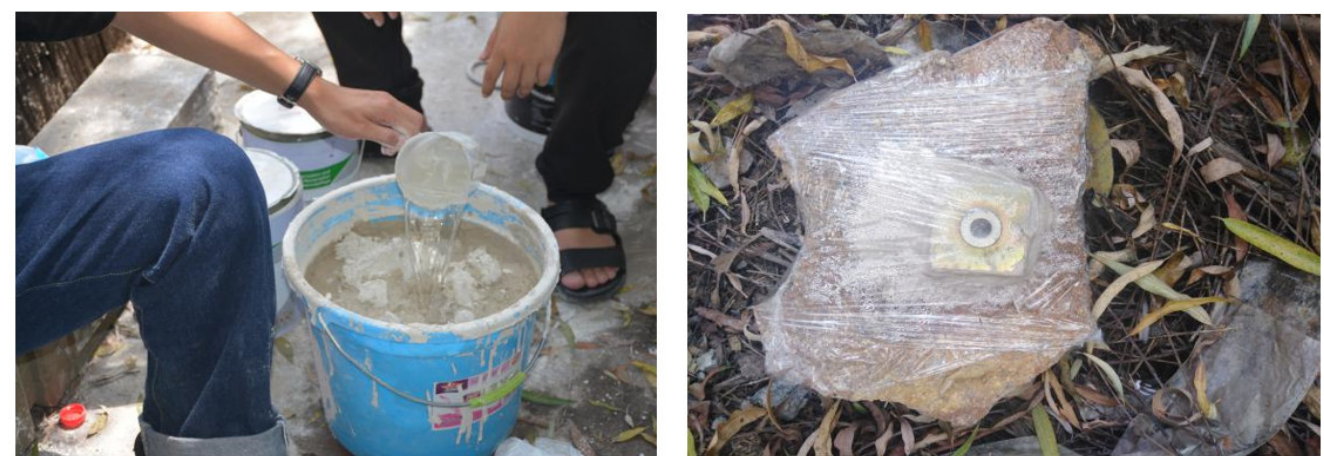

Figure 5 Make the Test Block

\section{B. Fabrication of Bending and Compression Test Block}

Put water, lime, mineral powder and various additives into corresponding containers according to the repair ratio after material optimization

(1) Mix manually and then mix evenly with mixer.

(2) Then pour a certain number of compression and bending test pieces in the corresponding mold.

(3) Finally, the casting mould shall be maintained for three days. 
(4) After forming, the formwork shall be removed and placed near or under the bridge for maintenance.
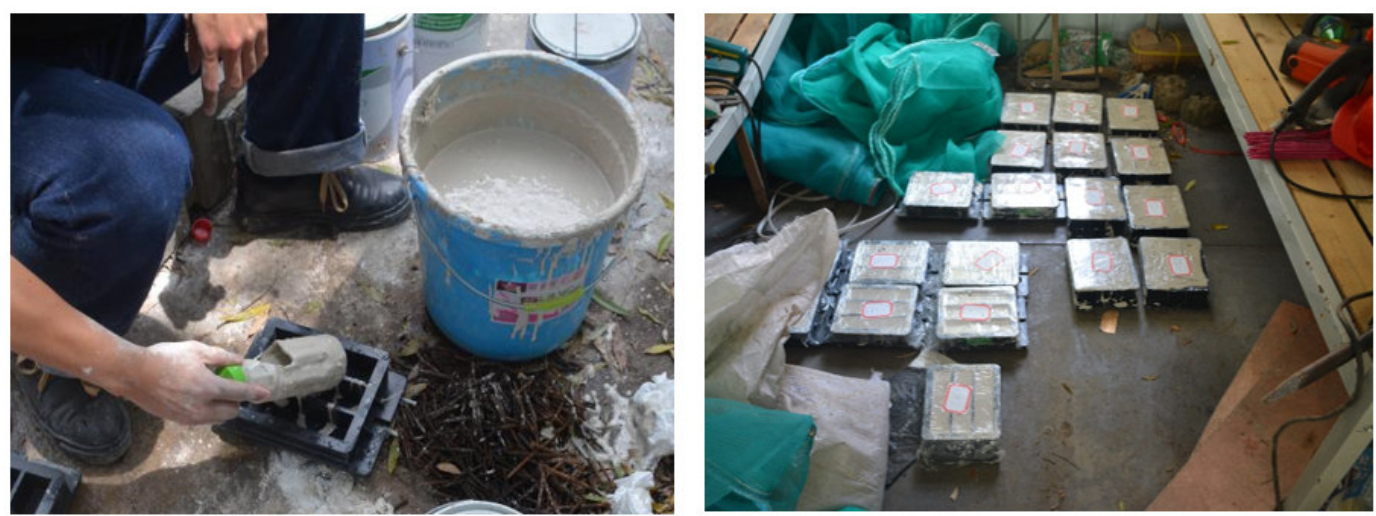

Figure 6 Make the Test Block

\subsubsection{Test Method and Content of Reserved Sample Test Block}

\section{(1) bond strength}

The bond strength is to apply different proportion of hydraulic lime paste to the standard test iron, then press the iron coated with hydraulic lime paste lightly on the stone surface with 20 ton force, and test the bond strength of the iron with HC-2000A intelligent bond strength tester 28 days later.

\section{A.Test principle}

$\mathrm{R}=\mathrm{X} / \mathrm{S}$

Where R -- bond strength (MPA);

$\mathrm{X}$-is the adhesion reading $(1 \mathrm{~N})$;

$\mathrm{S}$-- Tensile area of the sample $\left(\mathrm{mm}^{2}\right)$.

B.Test result evaluation

- The bending strength of each test piece is accurate to $0.01 \mathrm{MPa}$.

- Take the average value of the bond strength results of a group of three specimens as the experimental results. When any of the three strength values exceeds $\pm 10 \%$ of the average value, the average value shall be taken as the bond strength test result after elimination. The experimental results are accurate to $0.01 \mathrm{MPa}$.

\section{(2) Bending strength test}

The test method is in accordance with the test method for strength of cement mortar (ISO method) (GB / T17671-199). The size of the test piece is $40 \mathrm{~mm} \times 40 \mathrm{~mm} \times 160 \mathrm{~mm}$. The test piece is demoded after pouring for three days. It is naturally cured near the Guifang bridge environment. The test curing period is $28 \mathrm{~d}$.

\section{A.Test Principle:}

$\mathrm{RB}=\mathrm{PL} / \mathrm{BH}^{2}$

Where: RB - flexural (tensile) strength of concrete (MPa);

$\mathrm{P}$ - ultimate failure load of test piece (n);

$\mathrm{L}$ - distance between supports $(\mathrm{L}=100 \mathrm{~mm})$;

B - width of test piece (mm);

$\mathrm{H}$ - height of test piece ( $\mathrm{mm})$.

\section{B.Evaluation of Test Results:}

- The bending strength of each specimen is accurate to $0.1 \mathrm{MPa}$.

- Take the average value of the bending resistance results of a group of three specimens as the experimental results. When any of the three strength values exceeds $\pm 10 \%$ of the average value, the average value shall be taken as the experimental result of flexural strength after elimination. The experimental results are accurate to $0.1 \mathrm{MPa}$.

\section{(3) Compressive Strength Test}

The test method is in accordance with the test method for strength of cement mortar (ISO method) (GB / T17671-199). The size of the test piece is $40 \mathrm{~mm} \times 40 \mathrm{~mm} \times 160 \mathrm{~mm}$. The test piece is demoulded after pouring for three days. It is naturally cured near the Guifang bridge environment. The test curing period is $28 \mathrm{~d}$. The relative error (accuracy) of indication shall not be greater than $1 \%$. The range application shall make the expected failure load value of the test piece not less than $20 \%$ of the full range, nor more than $80 \%$ of the full range. The upper and lower part of the testing machine shall have sufficient rigidity, and one of them shall be equipped with spherical bearing, so that the contact between them and the bearing is even. Mold test, steel ruler: measuring range: $300 \mathrm{~mm}$, division value: $1 \mathrm{~mm}$. 


\section{A.Test Principle:}

$\mathrm{Rc}=\mathrm{P} / \mathrm{A}$

Where: $\mathrm{R}$ - compressive strength of concrete $(\mathrm{MPa})$;

$P$ - Ultimate failure load of test piece (n);

A - Compression area $\left(\mathrm{mm}^{2}\right)$;

Rc - compressive strength of concrete $\mathrm{Rb}$, accurate to $0.01 \mathrm{Mpa}$.

B.Evaluation of test results:

- The compressive strength of each specimen is accurate to $0.1 \mathrm{MPa}$.

- Take the arithmetic mean value of six compressive strength measured values obtained from a group of three test blocks as the experimental results. If one of the six measured values exceeds $\pm 10 \%$ of the six average values, this result shall be eliminated and the remaining five average values shall be taken as the result. If there are more than $\pm 10 \%$ of the five measured values, the results of this group will be invalid. The experimental results are accurate to $0.1 \mathrm{MPa}$.

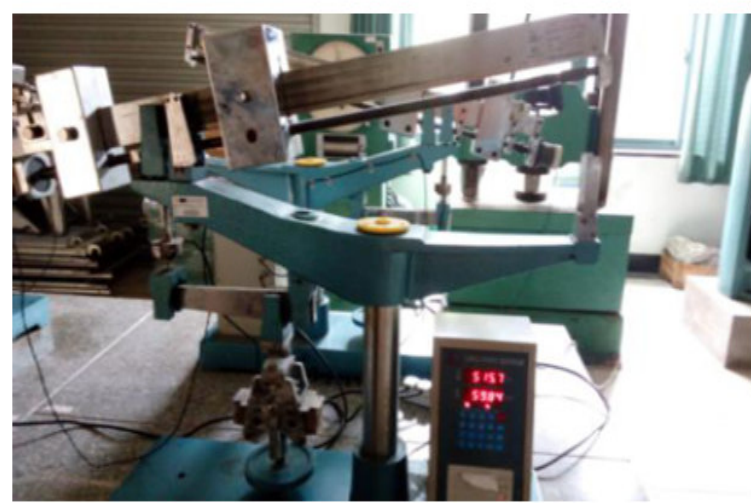

Figure 7 Bending Strength Test

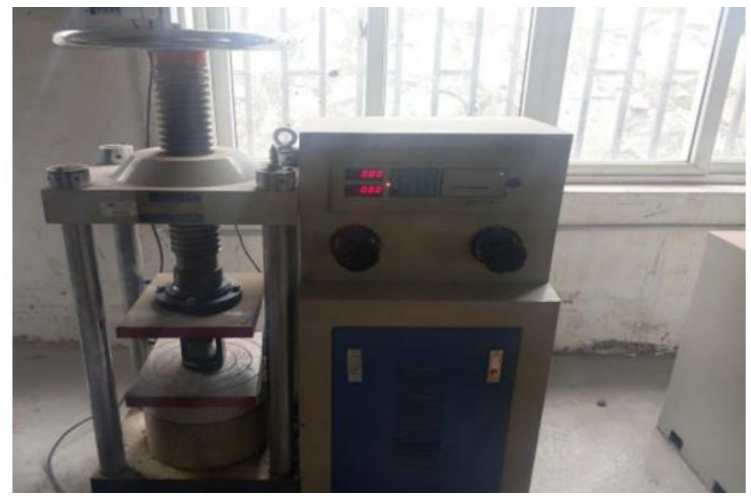

Figure 8 Compressive Strength Test

\subsection{On Site Bridge Deck Crack Grouting Construction}

\subsubsection{Construction Observation}

Firstly, the pollutants inside the cracks shall be cleaned with brush, high-pressure air and vacuum cleaner, and then the cracks shall be sealed with repair materials. After the sealing and repair materials are hardened, the hydraulic lime grouting materials shall be sucked by the grouting machine for pressure grouting treatment, and the grouting height shall not exceed $10-15 \mathrm{~cm}$ each time. The time interval for step grouting shall be $24 \mathrm{~h}$, and the grouting shall be carried out after the previous grouting is completely solidified. The grouting sequence is from the bottom to the top. In case of slurry overflow, grouting shall be stopped; at the same time, attention shall be paid to grouting to prevent slurry leakage in other places. In case of slurry leakage, it shall be blocked in time. After grouting, the external surface shall be pointed and trowelled with stone powder of the same material, and the old treatment shall be carried out at the same time.

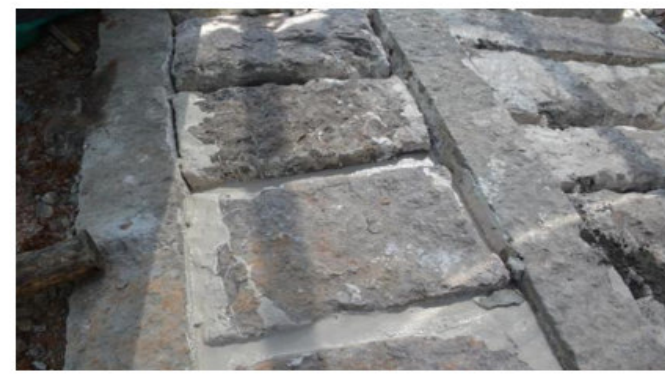

Figure 9 Grouting

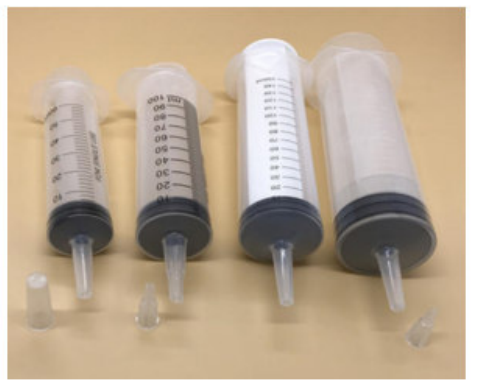

Figure 10 Grouting Tools

\subsubsection{The Appearance of Bridge Arch is Old}

According to the special project of science and technology protection of Guifang bridge, after the repair, the external surface is treated as new ones so that there is no obvious construction trace on the appearance of the bridge. For the materials, the exterior color matching agent SA90 of Shanghai dessaibao is selected.

steps

- $\quad$ Red, yellow and black pastes shall be mixed, and the total amount of color pastes shall not exceed 3\% of the total amount of color matching agent.

- The base surface must be dry and clean, free of dirt, weathering, alkali, algae and moss.

- Defects of the base surface, such as cracks, cracked joints, joints, rising steam, etc., must be repaired 
first.

- The product can be applied to the surface to be treated by brush or low-pressure spraying equipment. The newly treated surface shall be protected from rain within 5 hours.
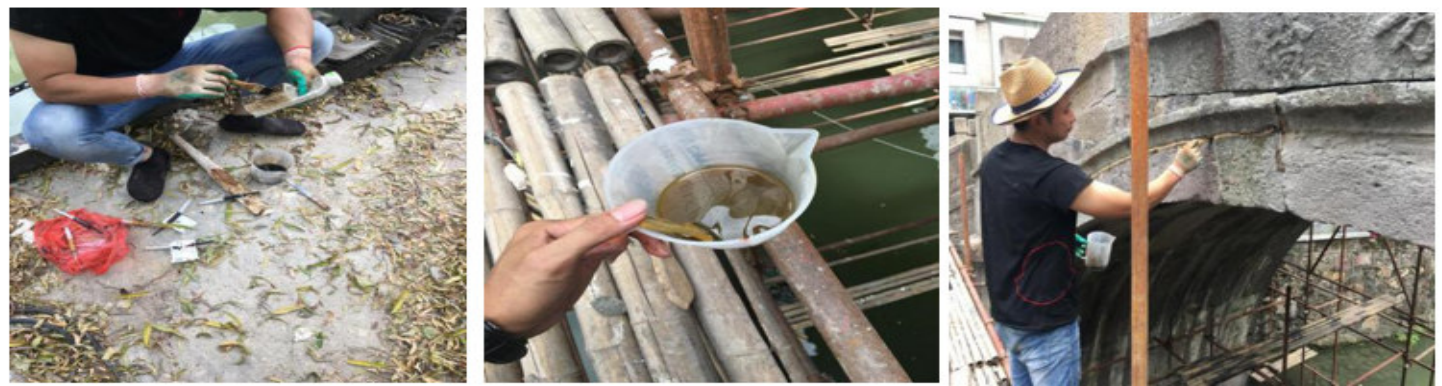

Figure 11 Getting the Crack Old

\subsubsection{On site construction effect detection}

The visual inspection shows that the color of the repair construction site is similar to that of the stone on both sides.
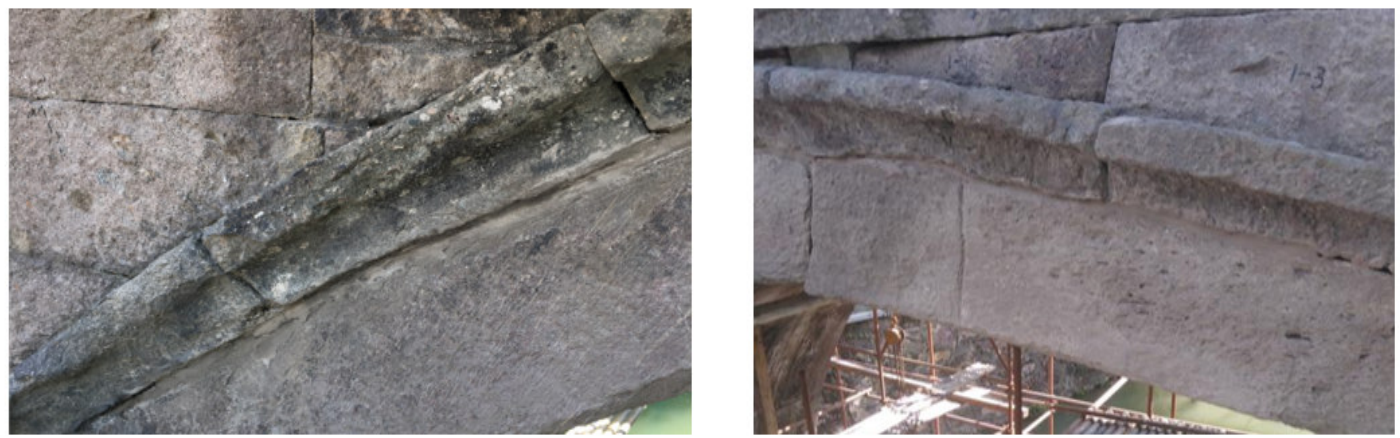

Figure. 12 Effect Detection

\section{Quality Control Measures}

(1) Check whether all kinds of pollution on the surface of bridge are effectively clear before and after being clear through photo comparison, and restore the color of the stone of cultural relics;

(2) The surface of bridge before and after cleaning shall be inspected by color difference meter. After cleaning, the color difference brightness will increase or remain unchanged;

(3) Use hardness tester to test the surface hardness of cultural relics before and after cleaning. After cleaning, the surface hardness of cleaning parts increases or remains unchanged;

(4) Detect the water absorption of the surface of the cultural relics after cleaning, indirectly judge that all kinds of blockage pollutants in the surface pores of bridge are effectively removed, and the water content of the surface increases or remains unchanged after cleaning.

\section{Conclusion}

The ancient stone bridge reinforcement repair method and quality control has been thoroughly researched. The repair procedure has been the best by the researcher in the order of how the whole repair process is been done. A conclusion is drawn after the whole work on how design princples are constantly maintain.

- Principle of "not changing the original state of cultural relics"

- Principle of "safety first"

- Principle of "quality first"

- Prevention of protective damage

- $\quad$ Principle of reversibility and reprocess ability

The researcher finally notice the people of China and the government as a whole did not change the face of their cultural relics as far as stone bridge is concern to date but rather protecting it for new generation come.

\section{Acknowledgements}

This work was financially supported by the Science foundation of zhejiang province, China (LGF20E080005). 


\section{Reference:}

[1] Zhongfu Xiang. Bridge Engineering Control. Beijing: China Communications Press.2011

[2] Yanran Yu, Wang bin. Technology research for Jiu Qu He Bridge Reinforcement Engineering's Construction Monitoring. Guangxi: Western China. 7, 2011, p.1-5(in China).

[3] WANG BO-HUI, Selection from Wang Bo-hui's paper, The People's Communication Press Beijing, 2004.

[4] Mao Yisheng. History of Ancient Bridge Technology of China, Beijing Press. 1986, 05. 